
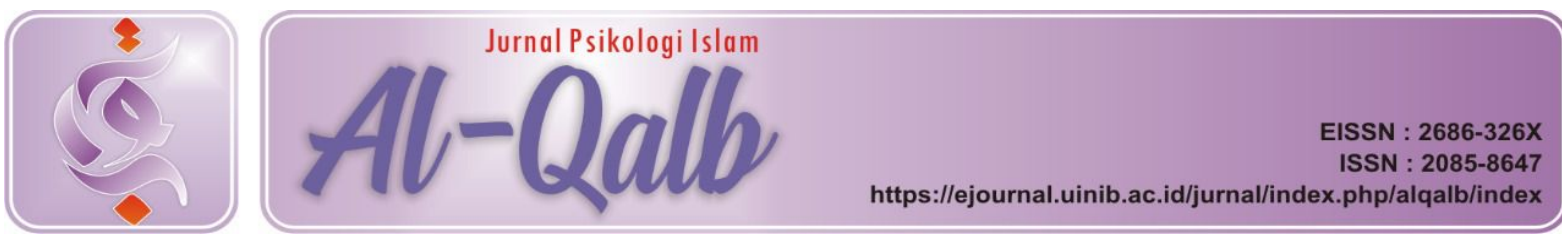

\title{
KONSEP DIRI PADA PRIA BISEKSUAL (Studi Kasus Pada ZB)
}

Received: 27th March 2019; Revised: 11 ${ }^{\text {th }}$ April 2019; Accepted: $24^{\text {th }}$ April 2019

\section{Rudi Gustian}

Universitas Islam Negeri Imam Bonjol Padang

Email: rudigustian79@gmail.com

\section{Hasnawati}

Universitas Islam Negeri Imam Bonjol Padang

Email: hasnawati@gmail.com

Rena Kinnara Arlotas

Universitas Islam Negeri Imam Bonjol Padang

Email: qhynnara@gmail.com

\begin{abstract}
ABSTRAK. Penelitian ini bertujuan untuk mengetahui bagaimana konsep diri pria biseksual dan faktor apa saja yang mempengaruhi konsep diri pada pria biseksual di Nagari $\mathrm{X}$ Kecamatan X Kabupaten $\mathrm{X}$. Penelitian ini menggunakan metode penelitian kualitatif dengan model studi kasus. Subjek dalam penelitian ini hanya satu orang. Pengumpulan data dilakukan dengan cara observasi dan wawancara. Adapun analisis data yang digunakan adalah pengumpulan data, reduksi data, display data, dan kesimpulan atau verifikasi. Hasil penelitian menunjukkan bahwa subjek mengetahui bahwa dari kecil ia memiliki sifat kewanitaan dan pernah mengalami pelecehan seksual, subjek masih melakukan hubungan sesama jenis meskipun telah menikah, subjek memiliki hubungan yang kurang dekat dengan keluarga dan lebih dekat dengan temanteman LGBT, dan subjek menikmati hidupnya sebagai biseksual. Adapun faktor-faktor yang mempengarahui konsep diri pada subjek adalah pada waktu kecil subjek diperlakukan seperti perempuan, pada waktu SD subjek mengalami pelecehan seksual sehingga pada akhirnya kecanduan dan menyukai laki-laki. Sehingga pada sampai saat sekarang subjek sulit untuk merubah perilaku biseksualnya.
\end{abstract}

Kata Kunci: Konsepdiri, Biseksual

\section{PENDAHULUAN}

negara liberal yang memberikan pengakuan dan tempat bagi komunitas LGBT di

Pada saat ini fenomena lesbian, gay, masyarakat. LGBT dianggap sebagai life style biseksual, dan transgender (LGBT) menjadi masyarakat modern yang menganggap isu yang banyak diperbincangkan di tengah pandangan heteroseksualitas sebagai masyarakat Indonesia dengan maraknya konservatif dan tidak berlaku bagi semua promosi atau iklan kaum LGBT di media orang (Rustam, 2016).

sosial. Propaganda perekrutan oleh kaum Istilah "bisexual" muncul belakangan, LGBT telah menyentuh berbagai media sosial, tepatnya, setelah diketahui bahwa ada orang bahkan kelompok LGBT juga sudah menjalar yang mempunyai orientasi seksual terhadap ke kampus, sekolah, dan tempat umum sesama jenis dan lawan jenis. Walaupun lainnya. Berbagai lembaga survei independen sebagian orang beranggapan bahwa biseksual dalam dan luar negeri menyebutkan bahwa di sebenarnya adalah kaun gay atau lesbian yang Indonesia ada 3\% kaum LGBT dari total takut atau malu untuk menyatakan diri penduduknya. Maraknya fenomena LGBT di Indonesia sangat terkait dengan tren negara- 
sebagai gay, istilah ini tetap bertahan dipersepsi seseorang tentang dirinya akan dan dipakai dalam banyak pembicaraan mempengaruhi penilaian terhadap dirinya (Sinyo, 2014). sendiri. Konsep diri dapat berbentuk konsep

Berdasarkan kamus lengkap Psikologi diri yang positif maupun yang negatif, tertulis bisexuality (biseksualitas, seksualitas tergantung dari diri individu sendiri. Pada ganda) memiliki ciri-ciri karakteristik dasarnya konsep diri terbentuk melalui proses anatomis dan psikologis dari kedua jenis belajar sejak masa pertumbuhan seseorang kelamin. Keadaan merasa tertarik sama dari kecil sampai dewasa (Tutut, 2010).

kuatnya pada kedua jenis kelamin, perempuan Berpikir mengenai dirinya sendiri maupun laki-laki (Chaplin, 2006). Sedangkan adalah aktivitas manusia yang tak dapat dalam buku Mengenal Perilaku Abnormal dihindari pada umumnya, secara harfiah dijelaskan Biseksual, yaitu orang-orang yang orang akan berpusat pada dirinya sendiri. mempraktikkan baik homoseksualitas maupun Sehingga self adalah pusat dari dunia sosial heteroseksualitas sekaligus (Kanisius, 1995). setiap orang. Sementara, seperti yang telah Coleman (dalam Kanisius, 1995) biseksual kita ketahui, faktor genetik memainkan yaitu orang-orang yang mempraktikkan baik sebuah peran terhadap identitas diri, atau homoseksualitas maupun heteroseksualitas konsep diri, yang sebagian besar didasarkan sekaligus. pada interaksi dengan orang lain yang

Tindakan homoseksual tidak saja dipelajari dimulai dengan anggota keluarga dicatat serta dipelajari oleh para ahli sejarah terdekat, kemudian meluas ke interaksi dan arkeologi, kita masih mempunyai catatan dengan mereka di luar kelurga. Walaupun sejarah tersendiri dari agama Samawi. Seperti orang sering kali berusaha untuk mengubah diketahui, kitab-kitab agama Samawi, konsep diri mereka, perubahan tersebut pada terutama Al-qur'an, selama ini diakui para umumnya terjadi sebagai akibat dari berbagai ahli sejarah, ahli arkeologi, ahli bahasa, ahli faktor daripada keinginan untuk memperbaiki kedokteran, serta ilmuwan lainnya sebagai diri (Byrne, 2003).

peninggalan yang berharga bagi ilmu Setiap orang berhak bahagia dan pengetahuan (Sinyo, 2014). sejahtera secara psikologis, akan tetapi untuk

Salah satu sejarah tentang LGBT yang mencapai kebahagiaan banyak dipengaruhi digambarkan dalam Al-Qur'an adalah kisah berbagai faktor, seperti emosi, kesehatan fisik, pengikut Nabi Luth atau dikenal dengan kaum kelekatan dan relasi, status sosial dan Sodom. Menurut agama Islam dalam Al- kekayaan, serta pencapaian tujuan (Ryan \& Qur'an, negeri Sodom dihancurkan karena Deci, 2001). Oleh karena itu, setiap manusia perilaku keji kaum Nabi Luth yang baru mempunyai kendala atau tantangan sendiri pertama kali dilakukan di muka bumi. Tidak dalam mencapai kondisi psikologis yang ada kaum-kaum sebelumnya yang melakukan sejahtera. Salah satu orang yang diduga tindakan tersebut. Kekejian yang dimaksud mengalami kendala dalam mencapai hal ini adalah tindakan homoseksual, yaitu adalah seorang biseksual.

melepaskan syahwat kepada sesama laki-laki Berdasarkan data Komisi dan bukan kepada wanita (Sinyo, 2014). Penanggulangan AIDS Nasional (KPAN)

Perilaku menyimpang tersebut tentu tahun 2016, terdapat 15.105 orang LGBT tidak terlepas dari peranan konsep diri (Lesbian, Gay, Biseksual, dan Transgender) individu. Self concept adalah kumpulan di Sumatera barat, yang terdiri 14.252 LSL keyakinan dan persepsi diri mengenai diri (lelaki suka lelaki) dan waria 853 orang. Di sendiri yang terorganisasi (Byrne, 2003). Kabupaten Padang pariaman terdapat LSL Konsep diri sangat berhubungan dengan 750 dan waria 34 orang. Angka tersebut pengalaman sosial, seperti misalnya identitas menempati posisi ke lima jumlah terbanyak pribadi seorang individu tergantung pada LGBT setelah Pasaman Barat dengan jumlah hubungannya dengan orang lain. Apa yang LSL 870 dan waria 50 (Harian haluan, 2018). 
Saat ini memang sudah cukup banyak

Model penelitian ini ialah model studi kaum biseksual yang mau terbuka tentang kasus yang memfokuskan pada kasus tertentu. keadaannya yang Biseksual, namun masih Creswell (1998) menyatakan bahwa studi juga ada yang enggan terbuka dan jumlahnya kasus (case study) adalah suatu model yang mungkin jauh lebih besar dari yang bisa menekankan pada eksplorasi dari suatu terbuka. Untuk kaum biseksual yang terbuka, "sistem yang berbatas" (bounded system) mereka mau membuka diri terhadap pada satu kasus atau beberapa kasus secara pergaulan sekitarnya, mereka juga tidak malu mendetail disertai dengan penggalian data lagi memperlihatkan keberadaan dirinya secara mendalam yang melibatkan beragam dengan kaum biseksual lainnya bahkan sumber informasi yang kaya akan konteks. mereka juga tidak malu jika terlihat sedang Studi kasus adalah suatu model penelitian bersama pasangannya yang satu jenis kelamin kualitatif yang terperinci tentang individu atau dengannya. suatu unit sosial tertentu dalam kurun waktu

Apalagi saat ini sudah didukung tertentu. Salah satu ciri khas studi kasus dengan perkembangan teknologi yang bisa adalah adanya "sistem yang berbatas" lebih spesifik dapat membantu biseksual satu (bounded system). Hal yang dimaksud dengan dengan biseksual lainnya bertemu, Facebook, sistem yang berbatas adalah adanya batasan Twitter, Blog hal seperti itu sudah pasti dalam hal waktu dan tempat serta batasan digunakan oleh mereka namun melalui dalam hal kasus yang diangkat dapat berupa aplikasi percakapan sosial khusus biseksual program, kejadian, aktivitas, atau subjek yang dengan bebas dapat di unduh oleh penelitian (Herdiansyah, 2014).

siapapun semakin mempermudahnya. Semua

itu mereka lakukan untuk tetap dapat PEMBAHASAN

membangun sebuah hubungan di dunia maya. Konsep diri adalah apa yang Untuk di dunia nyata sendiri, biseksual ini dipikirkan dan dirasakan tentang dirinya sering menunjukkan bahwa mereka itu ada sendiri. Ada dua konsep diri, yaitu konsep diri dengan muncul dan sering bergaul di tempat- komponen kognitif dan konsep diri komponen tempat ramai (Sukma, 2014).

afektif, komponen kognitif disebut self image

Berdasarkan uraian di atas, peneliti dan komponen afektif disebut self esteem. tertarik ingin melakukan penelitian mengenai Komponen kognitif adalah pengetahuan "Konsep Diri Pada Pria Biseksual (Studi individu tentang dirinya mencakup Kasus Pada ZB di Nagari X Kecamatan X pengetahuan “ siapa saya” yang akan Kabupaten X)".

\section{METODE PENELITIAN}

memberikan gambaran tentang diri saya. Gambaran ini disebut citra diri. Sementara itu, komponen afektif merupakan penilaian

Penelitian ini merupakan penelitian individu terhadap dirinya sendiri yang akan lapangan atau (field research), menggunakan membentuk bagaimana penerimaan terhadap pendekatan kualitatif yang merupakan metode diri dan harga diri individu (Ghufron, 2012).

untuk menemukan secara spesifik dan realistis Dalam melihat gambaran konsep diri tentang apa yang terjadi pada suatu saat di ini, perlunya mengetahui dimensi-dimensi tengah-tengah kehidupan masyarakat. konsep diri serta faktor-faktor yang Penelitian kualitatif adalah penelitian yang mempengaruhi konsep diri tersebut. Dimensibermaksud untuk memahami fenomena dimensi konsep diri ini meliputi, pengetahuan, tentang apa yang di alami oleh subjek harapan dan penilian, sedangkan faktor-faktor penelitian, untuk menghimpun data dengan yang mempengaruhi konsep diri terdiri dari mengungkap data dan menggambarkan peran orang tua (mengenai pola asuh), faktor kejadian-kejadian atau fenomena yang terjadi sosial dan belajar, dijelaskan sebagai berikut: di lapangan dengan sebagaimana adanya (Moleong, 2011). 
1. Gambaran konsep diri dilihat dari dimensi-dimensi konsep diri:

a. Pengetahuan

Dimensi pertama dari konsep diri adalah apa yang kita ketahui tentang diri sendiri atau penjelasan dari "siapa saya" yang akan memberi gambaran tentang diri saya. Gambaran diri tersebut pada gilirannya akan membentuk citra diri. Gambaran diri tersebut merupakan kesimpulan dari: pandangan kita dalam berbagai peran yang kita pegang, seperti orang tua, suami atau istri, karyawan, pelajar, dan seterusnya; pandangan kita tentang watak kepribadian yang kita rasakan ada pada diri kita, seperti jujur, setia, gembira, bersahabat, aktif, dan seterusnya; pandangan kita tentang sikap yang ada pada diri kita; kemampuan yang kita miliki, kecakapan yang kita kuasai, dan berbagai karakteristik lainnya yang kita lihat melekat pada diri kita. Intinya, dimensi pengetahuan (kognitif) dari konsep diri mencakup tentang diri kita sebagai pribadi, seperti "saya pintar, "saya cantik, "saya anak baik" dan seterusnya (Desmita, 2010).

Dalam Islam juga dijelaskan bagaimana pengetahuan tentang gambaran diri dan peran kita terhadap diri sendiri dan keluarga, hal ini dijelaskan oleh beberapa dalil sebagai berikut: "Hai orang-orang yang beriman, bertakwalah kepada Allah dan hendaklah Setiap diri memperhatikan apa yang telah diperbuatnya untuk hari esok (akhirat); dan bertakwalah kepada Allah, Sesungguhnya Allah Maha mengetahui apa yang kamu kerjakan" (Q. S AlHasyr). "Hai orang-orang yang beriman, peliharalah dirimu dan keluargamu dari api neraka yang bahan bakarnya adalah manusia dan batu; penjaganya malaikatmalaikat yang kasar, keras, dan tidak mendurhakai Allah terhadap apa yang diperintahkan-Nya kepada mereka dan selalu mengerjakan apa yang diperintahkan" (Q.S At-tahrim). "Sesungguhnya kamu mendatangi lelaki untuk melepaskan nafsumu (kepada mereka), bukan kepada wanita, malah kamu ini adalah kaum yang melampaui batas" (Q.S. Al-A'raf)

Pada dimensi pengetahuan ini, subjek mengetahui bahwa dari kecil ia memiliki sifat kewanitaan dan pernah mengalami pelecehan seksual. Subjek menyadari bahwa ia suka sesama jenis sejak masih kelas lima SD. Kemudian setelah tamat sekolah subjek pernah menjadi waria. Sebagai seorang suami, subjek tetap berusaha menjalankan perannya. Subjek masih melakukan hubungan sesama jenis ketika setelah menikah. Subjek rajin bersedekah tapi shalatnya masih ada yang bolong-bolong. Subjek juga pernah berbohong tapi ZB rajin bekerja dan bertanggung jawab dengan pekerjaannya dan juga aktif dilingkungan.

Berdasarkan beberapa dalil di atas, subjek hendaknya memperhatikan apa yang telah ia perbuat dalam hidupnya untuk hari esoknya. Sebagai kepala keluarga subjek harusnya menjadi imam yang baik untuk keluarganya supaya bisa mengajak kebaikan, agar terhindak dari siksa api neraka. Subjek merupakan seorang biseksual yang juga melapaskan nafsunya kepada sesama jenis.

b. Harapan

Dimensi kedua dari konsep diri adalah dimensi harapan atau diri yang dicita-citakan dimasa depan. Ketika kita mempunyai sejumlah pandangan tentang siapa kita sebenarnya, pada saat yang sama kita juga mempunyai sejumlah pandangan lain tentang kemungkinan menjadi apa diri kita di masa mendatang. Intinya, kita juga mempunyai pengharapan bagi diri kita sendiri. Pengharapan ini merupakan diri-ideal (self-ideal) atau diri yang dicita-citakan (Desmita, 2010).

Dalam Islam juga banyak dijelaskan tentang harapan bagi seorang hamba kepada Allah untuk masa depannya yang lebih baik, salah satunya firman Allah 
SWT dalam Q.S Al-Maidah ayat 84: "Mengapa Kami tidak akan beriman kepada Allah dan kepada kebenaran yang datang kepada Kami, Padahal Kami sangat ingin agar Tuhan Kami memasukkan Kami ke dalam golongan orang-orang yang saleh?".

Pada dimensi harapan ini, subjek berharap dirinya bisa menjadi orang yang normal dalam menjalani hidupnya. Kendala ZB untuk berubah dengan alasan media sosial dan $\mathrm{ZB}$ ingin mengurangi waktu untuk media sosial. Meskipun demikian, ZB berharap tidak ada yang mengetahui bahwa dia merupakan seorang biseksual.

Berdasarkan dalil di atas, subjek juga berkeinginan untuk berubah dan berharap tidak mengulangi kesalahannya. Hendaknya subjek lebih meningkatkan iman dan ketakwaannya kepada Allah SWT.

c. Penilaian

Dimensi ketiga dari adalah penilaian kita terhadap diri kita sendiri. Penilaian diri sendiri merupakan pandangan kita tentang harga atau kewajaran kita sebagai pribadi. Menurut Calhoun dan Acocella (dalam Desmita, 2010), setiap hari kita berperan sebagai penilai tentang diri kita sendiri, menilai apakah kita kita bertentangan: 1) pengharapan bagi diri kita sendiri (saya dapat menjadi apa), 2) standar yang kita tetapkan bagi bagi diri kita sendiri (saya seharusnya menjadi apa). Hasil dari penilaian tersebut membentuk apa yang disebut dengan rasa harga diri, yaitu seberapa besar kita menyukai diri sendiri. Orang yang hidup dengan standar dan harapan-harapan untuk dirinya sendiri-yang menyukai siapa dirinya, apa yang sedang dikerjakannya, dan akan kemana dirinya- akan memiliki rasa harga yang tinggi (high self-esteem). Sebaliknya, orang yang terlalu jauh dari standar dan harapan-harapannya akan memiliki harga diri yang rendah (low self-esteem). Dengan demikian dapat dipahami bahwa penilaian akan membentuk penerimaan diri (selfacceptance), serta harga diri (self esteem) seseorang (Desmita, 2010).

Dalam Islam dijelaskan patokan untuk menjadi hamba yang teribaik dan tentunya tidak lepas dari penilaian kita terhadap diri kita sendiri, apakah sudah menjadi yang terbaik untuk diri sendiri dan orang lain. Ayat yang menjelaskan tentang penilaian ini adalah sebagai berikut: "kamu adalah umat yang terbaik yang dilahirkan untuk manusia, menyuruh kepada yang ma'ruf, dan mencegah dari yang munkar, dan beriman kepada Allah. Sekiranya ahli kitab beriman, tentulah itu lebih baik bagi mereka, di antara mereka ada yang beriman, dan kebanyakan mereka adalah orangorang yang fasik" (Q.S. Ali Imron). "Maka jika mereka bertaubat, itu adalah lebih baik bagi mereka, dan jika mereka berpaling, niscaya Allah akan mengazab mereka dengan azab yang pedih di dunia dan akhirat; dan mereka sekali-kali tidaklah mempunyai pelindung dan tidak (pula) penolong di muka bumi" (Q.S. AtTaubah).

Pada dimensi penilaian ini, menurut subjek kondisinya sekarang disebabkan oleh: subjek pernah mengalami pelecehan seksual sehingga kecanduan seks dengan bapak-bapak dan pada akhirnya subjek suka kepada laki-laki. Teman-teman dan keluarga subjek tidak mengetahui bahwa ia seorang biseksual. Subjek memiliki hubungan yang kurang dekat dengan keluaraga, jarang berkomunikasi dan subjek lebih terbuka dengan lingkungan di luar keluarga daripada keluarga sendiri.

Subjek menyadari bahwa apa yang dilakukan selama ini merupakan kesalahan, tapi karena telah menjadi kebiasaan subjek sulit untuk berubah. Subjek menerima bahwa dirinya 
seorang biseksual. Subjek menikmati hidupnya sebagai biseksual dan subjek merasa tidak ada perbedaan dengan orang yang normal dan bisa bergaul dengan lingkungan sekitar. Subjek mengatakan bahwa dirinya bisa diterima oleh lingkungan dikarenakan orang kebanyakan hanya mengetahui bahwa subjek memiliki sifat kewanitaan.

Dari beberapa dalil di atas, sebagai umat yang terbaik hendak subjek bisa menjalankan yang ma'ruf dan mencegah dirinya dari yang munkar, tapi sangat disayangkan subjek merupakan bagaian dari kebanyakan orang-orang yang fasik. Namun subjek menyadari apa yang telah diperbuatnya merupakan kesalahan.

2. Faktor-faktor yang mempengaruhi konsep diri:

a Peran orang tua (mengenai pola asuh) Mead (dalam Tutut, 2010) berpendapat bahwa ketika masih kecil, orang penting bagi seorang anak adalah keluarganya, terutama orang tua. Merekalah yang pertama menanggapi perilaku anak, sehingga secara perlahan terbentuklah konsep diri anak.

Dalam Islam jelas disebutkan bagaimana pentingnya peran orangtua untuk mendidik anak dan membentuk kepribadian anak. Salah satu dalilnya adalah hadist Rasulullah SAW: "Setiap bayi dilahirkan atas dasar fitrah, maka kedua orang tuanyalah yang menjadikannya Yahudi, Nasrani, atau Majusi” (HR Muttaq Alaih).

Pada faktor peranan orang tua ini, subjek merupakan satu-satunya anak laki-laki dari 4 bersaudara dan paling kecil. Oleh karena itu, orang tua subjek memperlakukan subjek layaknya anak perempuan.

Dari dalil di atas, orang tua subjek mendidik dan membesarkan subjek dengan cara memperlakukan seperti anak perempuan. Maka dari itu lah subjek menjadi seperti perempuan.

b Faktor sosial

Mead (dalam Tutut, 2010) berpendapat bahwa konsep diri terbentuk karena adanya interaksi seseorang dengan orang-orang disekitarnya. Struktur, peran status sosial merupakan gejala yang dihasilkan dari adanya interaksi antara individu yang satu dengan yang lain, antara individu dengan kelompok, ataupun kelompok dengan kelompok.

Dalam Islam juga dijelaskan bahwasannya lingkungan sekitar atau teman bergaul, berpengaruh terhadap sifat atau kepribadian kita, seperti dalil hadits dan Al-Qur'an sebagai berikut "Permisalan teman yang baik dan teman yang buruk ibarat penjual minyak wangi dan seorang pandai besi. Penjual minyak wangi mungkin akan memberimu minyak wangi, atau jika bisa membeli minyak wangi darinya, dan kalaupun tidak, harus tetap mendapatkan bau harum darinya. Sementara pandai besi, bisa jadi (percikan apinya) tentang pakaianmu, dan kalaupun tidak perlu tetap mendapatkan bau secepatnya yang tak sedap (HR. Bukhari dan Muslim). "dan bersabarlah kamu bersama-sama dengan orang-orang yang menyeru Tuhannya di pagi dan senja hari dengan mengharap keridhaan-Nya; dan janganlah kedua matamu berpaling dari mereka (karena) mengharapkan perhiasan dunia ini; dan janganlah kamu mengikuti orang yang hatinya telah Kami lalaikan dari mengingati Kami, serta menuruti hawa nafsunya dan adalah keadaannya itu melewati batas" (Q.S. Al-Kahfi).

Pada faktor sosial ini, subjek pada saat kelas 5 SD dirayu diberi uang dan makanan oleh bapak-bapak sampai menjadi kecanduan. Pada saat di panti Lubuk Alung disana hanya ada laki-laki, maka hal itu yang membuat subjek semakin menjadi-jadi. Setelah tamat 
sekolah subjek juga pernah menjadi seorang waria, tapi sekarang subjek penampilannya seperti laki-laki pada umumnya.

Dari beberapa dalil di atas, subjek yang bergaul dengan orang-orang biseksual dan gay, maka hal itu yang menyebabkan ia menjadi seorang biseksual. Hendaknya subjek tidak mengikuti mereka yang lalai hatinya dalam mengingat Allah dan menuruti hawa nafsunya, dan keadaannya yang melewati batas.

c Belajar

Mead (dalam Tutut, 2010) berpendapat bahwa konsep diri merupakan hasil belajar, proses belajar ini terjadi setiap hari dan umumnya tidak disadari oleh individu. Belajar disini dapat diartikan sebagai perubahan psikologis yang relatif permanen yang terjadi sebagai konsekuensi pengalaman.

Dalam Islam dijelaskan kita dari kecil hingga tua nanti merupakan proses belajar, baik itu untuk kehidupan dunia dan akhirat, tidak lupa pula kita belajar untuk memperbaiki kesalahan yang diperbuat, salah satu dalil yang mendukung adalah Q.S. Al-Maidah 105: "Hai orang-orang yang beriman, jagalah dirimu; Tiadalah orang yang sesat itu akan memberi mudharat kepadamu apabila kamu telah mendapat petunjuk. hanya kepada Allah kamu kembali semuanya, Maka Dia akan menerangkan kepadamu apa yang telah kamu kerjakan.

Pada faktor belajar ini, Pada awalnya subjek mengalami pelecehan seksual sehingga akhirnya subjek kecanduan. Karena memiliki sifat kewanitaan maka subjek juga pernah mendapatkan pelecehan seksual dari orang dekat rumahnya, ketika MAN subjek kembali mengalami pelecehan seksual dengan bapak-bapak.

Dari dalil di atas, dapat dipahami maksud dari belajar adalahh menjaga diri, subjek tidak akan mendapatkan mudharat kepadanya apabila telah mendapat petunjuk. Dari pengalaman subjek hendaknya dapat dijadikan pelajaran dan mendapat petunjuk untuk berubah.

\section{KESIMPULAN}

Gambaran konsep diri pada pria biseksual yang dilihat dari Dimensi-dimensi konsep diri meliputi: Pengetahuan, Harapan dan Penilaian. Dilihat dari dimensi pertama yaitu pengetahuan, subjek mengetahui bahwa dari kecil ia memiliki sifat kewanitaan dan pernah mengalami pelecehan seksual. Sebagai seorang suami, subjek tetap berusaha menjalankan perannya. Subjek masih melakukan hubungan sesama jenis ketika setelah menikah. Subjek kurang mendekatkan diri kepada Allah tapi ZB rajin bekerja dan juga aktif dilingkungan. Kemudian pada dimensi yang kedua yaitu harapan, subjek berharap dirinya bisa menjadi orang yang normal dalam menjalani hidupnya. Selanjutnya pada dimensi yang ketiga yaitu penilaian, subjek memiliki hubungan yang kurang dekat dengan keluarga dan lebih dekat dengan teman-teman LGBT, subjek menikmati hidupnya sebagai biseksual dan subjek merasa tidak ada perbedaannya dengan orang yang heteroseksual.

Faktor-faktor yang mempengarahui konsep diri pada pria biseksual adalah: peran orangtua (pola asuh), faktor sosial, dan belajar. Pada waktu kecil subjek diperlakukan seperti perempuan, pada waktu SD subjek mengalami pelecehan seksual sehingga pada akhirnya kecanduan dan menyukai laki-laki. Sehingga pada sampai saat sekarang subjek sulit untuk merubah perilaku biseksualnya.

\section{DAFTAR PUSTAKA}

Arif, Rusdi. (2015). Penyesuaian Diri Pria Biseksual Di Kampu X Padang Panjang. Skripsi: Institut Agama Islam Negeri Imam Bonjol Padang. Padang.

Baron, Robert, A \& Donn, Byrne. (2003). Social Psychology: Tenth Edition. Erlangga. 
61 Jurnal Al-Qalb, Jilid 10, Nomor 1, Maret 2019, hlm. 54-62

Kanisius. (1995). Mengenal Perilaku

Burns, R.B. (1993). Konsep Diri: Teori, Abnormal. Yogyakarta. pengukuran, perkembangan dan Kartono, Kartini. (2013). Patologi Sosial. perilaku. Jakarta: Arcan.

Chaplin, J.P. (2008). Kamus Lengkap Jakarta. PT Raja Grafindo Persada.

Masters, dk. (1928). Human Sexuality. Little Brown.

Psikologi. Jakarta. PT Raja Grafindo Moleong. (2011). Metodologi Penelitian Persada Universitas Gunadarma.

Kualitatif. Bandung: Remaja Rosdakarya.

Desmita, (2010). Psikologi Perkembangan

Peserta Didik. Bandung: PT Remaja Ni'matuzahroh \& Susanti Prasetyaningrum. Rosdakarya.

Digital, Al-qur'an. (2004).

Efendi, Sofyan. HaditsWeb.

Ghozali, A, M. (2017). Fenomena LGBT Dalam Perspektif HAM dan Doktrin Agama (Solusi dan Pencegahan). UIN Raden Intan Lampung. Refleksi Vol 16 No 1. 2014.Observasi dalam Psikologi. Malang:UMM Press.

Rustam, Dahar, K, A, Harahap. (2016). LGBT di Indonesia: Perspektif Hukum Islam, HAM, Psikologi dan Pendekatan Maslahah. Semarang: Universitas Islam Negeri Walisongo. ALHAKAM Vol 26 No 2.

Sarwono, Sarlito. (2002). Psikologi Remaja. Jakarta: Raja Grafindo Persada.

Ghufron, M. Nur. (2012). Teori-Teori Sianturi, EH. (2011). Psychological WellPsikologi. Jogjakarta. AR-RUZ MEDIA.

Herdiansyah, H. (2011). Metodologi Penelitian Kualitatif Untuk Ilmu Sinyo. (2014). Anakku Bertanya Tentang Sosial. Jakarta: Salemba Humanika.

Herma, Nadya, M. (2013). Kondisi Psikologis Pada Biseksual. Skripsi: Universitas Siregar, Cynthia. (2015). Profil Biseksual Di Islam Negeri Sunan Kalijaga. Kota Pekanbaru. Pekanbaru: Yogyakarta. Universitas Riau. Jom FISIP Vol 2 No 2.

https://www.harianhaluan.com di akses pada tanggal 2 Febuari 2019 pukul 20.00 Sobur. (2003). Psikologi Umum (Dalam WIB. Lintas Sejarah). Bandung: Pustaka Setia.

Jarvis Matt. (2006). Teori-Teori Psikologi:

Pendekatan Modern Untuk Memahami Sugiyono. (2011). Metode Penelitian Perilaku, Perasaan, dan Pikiran Kuantitatif Kualitatif R\&D. Bandung: Manusia. Bandung. Nusa Media. Alfabeta.

Jbptunikompp-gdl-bagussukma-34940-10unikom_b-i.pdf di unduh pada tanggal

Papilaya, J, Ophilia. (2016). Lesbian, Gay, 18 November 2018 pukul 19.15 WIB Biseksual, dan Transgender (LGBT) dan Keadilan Sosial. Jurnal Humaniora Yayasan Bina Darma Vol 3 No 1. 
62 Jurnal Al-Qalb, Jilid 10, Nomor 1, Maret 2019, hlm. 54-62

Vitasandy, Tutut, D \& Anita Z. (2010).

Konsep Diri Pria Biseksual.

Universitas Gunadarma. Jurnal

Psikologi Vol 3 No 2. 